Ann-Christin Torpsten

Högskolan i Kalmar

\begin{abstract}
The over all aim of this study was to analyse curricula and syllabuses concerning Swedish as a Second Language in compulsory basic school. Texts have been interpreted and analysed through a frame of conceptions in one monoculture and one multiculture prism. These prisms have been useful in creating different pictures of the subject. The analysis shows changes, breaks and double tracks with contradictory ideals. The result shows a subject growing from a need to keep prevailing order and to foster future citizens. Despite efforts towards multicultural ideals contemporary curricula is principally monocultural. A subject with dual educational ideals appears.
\end{abstract}

\title{
SVENSKA SOM ANDRASPRÅK I GRUNDSKOLANS STYRDOKUMENT
}

Andelen barn med utländsk bakgrund inom svensk för- och grundskola är ungefär femton procent (Myndigheten för skolutveckling, 2004; Skolverket, 2004). En del av denna grupp utgörs av elever med annat förstaspråk än svenska vilka deltar i undervisning och samtal med kamrater samt lärare på ett språk de inte behärskar fullt ut. Stora krav ställs både på andraspråkseleverna och på undervisande lärares förståelse för dessa elevers speciella situation liksom kunskap om elevgruppens behov av språkutvecklande insatser. Det ställs också stora krav på läro- och kursplaners formuleringar gällande andraspråksämnet

I den sammanställning som gjorts av nationella utvärderingen av grundskolans år 9, genomförd 2003, framkommer det att stor förvirring råder gällande bedömning av andraspråkselevers skolresultat. Trots att såväl lärar- som elevenkäter var framtagna både för svenska som förstaspråk och svenska som andraspråk, visade det sig att lärarna hade stora svårigheter att bedöma vilka elever som skulle komma i fråga för andraspråksenkäten. Detta berodde på att det var oklart vilka elever som undervisades i ämnet (Elmeroth, 2005a). En intervjuundersökning, med fokus mot hur verksamma lärare förhåller sig till läroplansskrivningar och vad de upplever som viktigt i sin undervisning gällande andraspråkselever, visade att en del lärare var väl insatta medan andra var dåligt insatta $i$ aktuella läro- och kursplaners uttryckta mål och innehåll. Resultatet visade att undervisningsfokus och undervisningsinnehåll inte alltid vara det samma som nuvarande läro- och kursplans. I samma undersökning blev, både verksamma lärares och blivande lärares, önskan om fortbildning och utbildning inom området tydlig (Torpsten, 2004). 
Ovanstående resonemang åskådliggör att det råder förvirring kring andraspråksämnet, att det åtminstone bland lärare är oklart vad som är mål och innehåll i skolämnet svenska som andraspråk, att det är oklart vilka elever ämnet är avsett för samt att både verksamma och blivande lärare önskar mer utbildning inom området. Jag menar därför att det är viktigt att fortsätta studera ovan nämnda med utgångspunkt $\mathrm{i}$ grundskolans styrdokumentsformuleringar.

\section{Syfte och uppläggning}

Denna artikel baseras på min licentiatavhandling (Torpsten, 2006) vars övergripande syfte var att synliggöra vad grundskolans andraspråksämne erbjuder andraspråkselever. Studien avsåg att analysera grundskolans styrdokument gällande ämnet svenska som andraspråk över tid. Analysen fokuserar kulturell reproduktion i termer av vad andraspråkselever erbjuds lära.

Med denna artikel vill jag delta i diskussionen och kunskapsutvecklingen kring andraspråkselevernas skolsituation och skolämnet svenska som andraspråk genom att anknyta till svensk läroplansteoretisk forskningstradition. Övergripande syfte är att analysera i läro- och kursplaner formulerade respektive konkretiserade ideal gällande svenska som andraspråk över tid. Inledningsvis redogör jag för studiens teoretiska utgångspunkter och utvecklar en tolkningsram med två prismor. Därefter genomför jag textanalyser i två steg. Avslutningsvis relateras och diskuteras de två analysstegens resultat.

\section{LÄROPLANSTEORETISK UTGÅNGSPUNKT}

Läroplaner är både generella och speciella dokument vilka dels bär spår av sin tid, dels är speciella dokument för styrning av skola och undervisning. I engelsk litteratur används begreppet curriculum som en generell term. I svensk kontext används begreppet läroplan för officiella och nationella styrdokument som styr skolverksamhet och undervisning. Förutom att läroplaner är pedagogiska texter som uttrycker skolans verksamhet är de också sociala konstruktioner där vad som i olika tider ansetts viktigt att undervisa om formulerats. På så vis uttrycks olika samhälles tänkande och idéer kring undervisning av barn och unga i texterna (Englund, 1986; 2005; Goodlad, 1979; Lundgren, 1979/1989; Popkewitz, 1997). Därmed är läroplanerna också planer för socialt lärande och erfarenhetsöverföring mellan generationer. I formuleringarna ryms dessutom de sammanhang i vilka innehållet ska tolkas och genomföras.

\section{Läroplaners framträdansformer}

Olika nivåer som beskriver hur läroplaner framträder kan utgöra struktur vid läroplansanalyser. Goodlad (1979) beskriver fem olika former som kan ligga till grund för studium och analys av curriculum. Ideological Curricula liksom Formal Curricula beskrivs som konsekvenser av de diskussioner, förarbeten och utredningar som föregår formulering av en text. De ideologier som slutligen formuleras är kompromisser, godkända av dominerande samhällsintressen kring vad som är viktigt att barnen lär. På så vis påverkas texterna av rådande kultur och traditioner. Perceived Curricula är beroende av lärares, föräldrars, elevers, administratörers och politikers tolkning av de formella dokumenten. Vid tolkning påverkas personerna av tolkningssammanhangens kultur och traditioner. Operational Curricula innebär curriculum i praktik dvs. hur 
lärare praktiserar den tolkade planens ideal och innehåll. Elevers och lärares upplevelser av läroplanen i form av vilka möjligheter elever ges för att nå formella läroplaners mål och hur lärandet mäts omfattas av Experienced Curricula (Goodlad, 1979). Denna artikel behandlar formerna Ideological Curricula och Formal Curricula vilka översatts till svenska begrepp, ideologisk läroplan och formell läroplan enligt nedanstående.

Ideologisk läroplan; konsekvenser av samhällspolitiska diskussioner kring idealt utbildningsinnehåll Formell läroplan; utbildningsideal framskrivna i formella dokument så som läro- och kursplaner

Figur 1. De former för framträdande som analyseras

Genom analys av läro- och kursplaner över tid blir det möjligt att synliggöra utbildningsideal gällande andraspråksämnet.

\section{Läroplaners bärande principer}

Grundläggande och bärande principer samt filosofier vilka Lundgren (1979/1989; 1984) och Englund (1986; 2005) betecknar läroplanskoder, beskriver relationer mellan nivåer. Koderna formas över tid och förändras i takt med att samhället och samhällets krav förändras. Den klassiska, den realistiska, den moraliska och den rationella läroplanskoden nämns av Lundgren $(1979 / 1989$; 1984) som exempel på övergripande läroplanskoder vilka kan urskiljas över tid. Klassisk läroplanskod omfattar klassisk bildning för barnen. Inom denna betonas humaniora och det antika kulturarvet. Realistisk läroplanskod understryker naturvetenskaper och bygger en länk mellan utbildning och krav från arbetslivet. Moralisk läroplanskod i sin tur betonar gudsfruktan, moral och fosterlandet. Rationell läroplanskod framhåller skolkunskap som är användbar både för samhället och för individen. Utbildningens funktion att kvalificera och differentiera arbetskraft betonas. Englund (1986, 1990, 2005) beskriver ytterligare en läroplanskod, den medborgerliga, där syftet med den gemensamma skolans utbildning av barnen är social integration, förändring och utbildning av medborgare i ett demokratiskt samhälle. Den medborgerliga läroplanskoden verkar sammanhållande. Genom utbildningen lär sig barnen dels sina medborgerliga och demokratiska rättigheter, dels sina skyldigheter.

\section{Läroplansteori och läroplansanalys}

Läroplansteori kan utgöra referensram för tolkning vid systematiskt genomförda studier av vad utbildning ska innehålla och hur den ska genomföras. Läroplanshistoriska analyser kan på så vis bidra till att synliggöra olika tiders sociala konstruktioner som förs vidare mellan generationer (Abrahamsson, 1999; Ball 1994; Englund, 1986; 2005; Goodlad, 1979; Lundgren, 1972; 1979/1989; 1981; 1984). Det läroplansteoretiska perspektivet fångar också rådande läroplanskoder (Englund, 1986; Abrahamsson, 1999). Härigenom kan förklaras varför vissa mål, visst innehåll och vissa metoder uttrycks i en läroplan. Kunskap kan också byggas om hur ett samhälle och en kultur formar.

\section{SKAPANDE AV MAKT OCH MENING}

Genom språket formuleras och konstrueras världen. Språk och begrepp kan därför ses som meningsskapande, som kulturella och gemensamma referensramar. När språket ses 
som meningsskapande får olika begrepp också makt (Nordin-Hultman, 2004; Säfström, 1998; 1999) och vad som kan tänkas eller sägas om något avgränsas (Alvesson \& Sköldberg, 1994; Ball 1994; Lindgren, 2000; Olsson, 1999). Ord kombineras på ett bestämt sätt som innebär att andra kombinationer utesluts (Ball, 1994). De som äger rätt att producera legitima kunskaper agerar för att utesluta vissa typer av kunskaper och för att legitimera egna idéer och utgångspunkter. Ett sätt för ett samhälle att upprätthålla makten är att uttrycka det som anses vara viktig kunskap i styrdokumenten för den obligatoriska skolan. På så vis utövas makt över dem som ska utbilda och utbildas, av dem som tillåtits tala i formulerandet av läroplaner. Metoden att i text tala om undervisning och undervisningsinnehåll kan därför ses som språkliga konstruktioner baserade på strukturer av makt i samhället (Popkewitz, 1997). Läro- och kursplanetexter uttrycker både makt och skapar mening då de formar en gemensam bild genom att texterna har formulerats. I och med att undervisningsinnehåll bestäms av dem som har makt att bestämma, förändras det över tid (Goodlad, 1979; Lundgren, 1984; 1992; 1999; Olsson, 1999; Säfström, 1998; 1999).

Exempel på språkliga konstruktioner som skapar mening när de formuleras i läro- och kursplaners texter är begreppen andraspråkselev och svenska som andraspråk. Rätten att formulera innehåll i utbildning och fostran beskrivs (Englund, 1986; 2005) som en kamp mellan olika värderingar och ideal där människor politiskt uttalar vad som är viktigt att kunna och veta. I denna maktkamp formuleras läroplaner genom kompromisser.

\section{CENTRALA BEGREPP OCH PRISMOR - PERSPEKTIV FÖR TOLKNING}

Läro- och kursplaners formuleringar är avgörande för utbildningens utformande eftersom de syftar till lärande av ett speciellt innehåll (Ried, 1999; Lundgren, 1999). Formuleringarna när det gäller svenska som andraspråk blir därför avgörande för vad andraspråkseleverna erbjuds lära. För att förstå erbjudet lärande utvecklas en tolkningsram bestående av två prismor. Det monokulturella prismat omfattar begreppen likformig/kompensera/begränsat deltagande. Det multikulturella prismat omfattar begreppen olikformig/komplettera/deltagande fullt ut. Prismorna och begreppen är centrala och möjliggör studiens analys. I följande text utvecklas prismornas innebörd med utgångspunkt $\mathrm{i}$ en diskussion kring de olika begreppen.

\section{Likformig/olikformig}

De stora krav på likvärdig utbildning i skolan, som ställs i mötet med elevers olika behov, diskuteras av Elmeroth (1997, 2005a) och Parszyk (1999). Dessa forskare menar att elever med invandrarbakgrund ofta betraktas som en homogen grupp, inte som olika individer. De är dock lika olika som elever med båda föräldrarna födda $\mathrm{i}$ Sverige. Forskarna menar att begreppen andraspråkselev och invandrarelev används på missvisande, kategoriserande och diskriminerande vis. Elevgruppen är heterogen, många av dem är födda i Sverige, andra har invandrat i tidiga år respektive i skolåldern. Men utifrån namn, utseende eller förstaspråk klassificeras hela gruppen som invandrare respektive invandrarelever som en homogen grupp.

Englund (1995; 1999) och Berg (2003) diskuterar innebörden i begreppet likvärdighet i skolsammanhang och i styrdokumentstexter. Likvärdig som begrepp har högt symbolvärde, är centralt i utbildningspolitik och håller samman det gemensamma. Alla 
barn ska garanteras en likvärdig utbildning och genom skolan fostras i jämlikhet och demokrati. Enligt dessa forskare har betydelsen av begreppet likvärdig dock förändrats över tid. Från betydelsen av likvärdig som lika innehåll, enhetlig och gemensam referensram genom grundläggande kunskaper i utbildningen har betydelsen av likvärdig förändrats till att innebära individuell och olik eftersom elever har olika behov och förutsättningar. Att utbildningen är likvärdig innebär att undervisningen utformas olika utifrån enskilda elevers olika behov och förutsättningar. Likvärdig betyder av jämlikhetsskäl därför inte likformig utan olikformig med differentiering och fostran till respekt för olika individers lika värde (Englund, 1999). Likvärdig innebär likvärdiga mål utifrån olika behov och förutsättningar. Genom jämförelser av hur begreppet används i olika läroplaner har Berg (2003) studerat likvärdighet som en fråga om olikhet. Begreppet jämlik i form av likvärdig/enhetlig har enligt Bergs (a.a.) diskussion ersatts med jämlik i betydelsen lika möjligheter. Nedanstående figur visar de diskuterade begreppen.

\begin{tabular}{|l|l|l|}
\hline Monokultur & Samma innehåll, behov och förutsättningar & Likformig \\
\hline Multikultur & Olika innehåll, behov och förutsättningar & Olikformig \\
\hline
\end{tabular}

Figur 2. Likformig respektive olikformig

Utifrån ovanstående resonemang framträder två utgångspunkter för tolkning. Med en monokulturell utgångspunkt är undervisningen likformig eftersom innehåll, elevers behov och förutsättningar är samma. En multikulturell utgångspunkt däremot innebär att undervisningen är olikformigt eftersom innehåll, elevers behov och förutsättningar är olika.

\section{Kompensera/komplettera}

Lahdenperä (1997) är kritisk till lärares förhållningssätt till andraspråkselever. Genom att i åtgärdsprogram uttrycka ett kompensatoriskt tänkande formulerar de ett förhållningssätt som är negativt och diskriminerande. Eleverna kategoriseras på ett sätt som kan skada och invandrarbakgrunden ses som en brist. Bristperspektivet bygger på ett slutet och monokulturellt synsätt med fokus på hinder, svårigheter, belastning samt uppfattningen att skolan kan kompensera föräldrarnas och hemmets brister. Tanken att något har brister utgår från att något annat är komplett. Hos elever med invandrarbakgrund kan svenskheten samt behärskandet av svenska språket upplevas som brister möjliga att kompensera. Skolans undervisning ska med hjälp av särskilda resurser kompensera eleverna. Det kompenserande och problematiserande sättet att tänka kring undervisning diskuteras även av Haug (1998), Karlsudd (2002) och Persson (2001). Enligt dessa forskare har specialundervisning i Sverige en tradition av kompenserande. Kunskap kring specialpedagogik bygger på uppfattningen att skolan genom undervisning kan kompensera brister. Karlsudd (a.a.) diskuterar ovanstående som motsägelsefulla kulturers organisation av segregerande och integrerande verksamhet.

Begreppet elever med invandrarbakgrund kan ersättas av begreppet multikulturella (Svenska Akademien, 1994) elever då gruppen är heterogen och varje elev har sin kombination av kulturer. Ur ett multikulturellt perspektiv som är öppet kan man se de multikulturella elevernas tidigare erfarenheter som resurser som kan tas tillvara för att komplettera. Multikulturella elever har i detta perspektiv tillgångar som berikar och 
vidgar. Sett ur samma perspektiv kan grundskolans undervisningsinnehåll uppfattas komplettera föräldrarna och hemmet. Ovanstående diskuterade begrepp visas i följande figur.

\begin{tabular}{|l|l|l|}
\hline Monokultur & Kulturell ensart, olikhet som brist, svårighet & Kompensera \\
\hline Multikultur & Kulturell mångfald, olikhet som resurs, möjlighet & Komplettera \\
\hline
\end{tabular}

Figur 3. Kompensera respektive komplettera

Utifrån ovanstående resonemang framträder ytterligare två utgångspunkter för tolkning. Med en monokulturell utgångspunkt kompenseras olikheter, svårigheter och brister genom undervisningens innehåll vilket leder till kulturell ensart. En multikulturell utgångspunkt däremot innebär att undervisningens innehåll kompletterar, att olikheter ses som resurser och möjligheter vilket leder till kulturell mångfald.

\section{Begränsat deltagande/deltagande fullt ut}

När det gäller ämnet svenska (som förstaspråk) har Malmgren (1996) och Elmeroth (2005b) utvecklat fyra olika ämneskonceptioner och Östman (1995) utvecklat ämnesfokus för naturkunskap. Ämneskonceptionerna visar vad som upplevs centralt och viktigt i ämnets undervisning och varför det uppfattas så. Eftersom både svenska (som förstaspråk) och svenska som andraspråk är språkämnen vilka har likheter kan samma begrepp användas för att beskriva andraspråksämnet. Östman (1995) talar om ämnesfokus vilket beskriver innehållsval i undervisning när det gäller naturkunskap. Ämnesfokus beskriver ämnets kärna och fokus samt elevers förhållande till ämnet och hur det ska behandlas. Relevant för denna studie är ämnesfokus som enligt Östmans (a.a.) beskrivning kan betecknas kunskap i och om språket för att hantera-var-dag, språket-som-förutsättning för att nå framgång och medvetenhet-för-förståelse.

\section{Ämneskonceptioner}

Svenska som andraspråk kan uppfattas som ett färdighetsämne (Malmgren, 1996) om innehållet domineras av språkets form med formell eller isolerad träning av olika språkliga moment och tekniker. I detta perspektiv kan innehållet genomföras som träning i att läsa högt eller övning i grammatik genom modellinlärning. Språkets form drillas genom att formen skiljs från innehållet. Inom färdighetsämnet tränas också studieteknik genom isolerade färdighetsövningar och träning av olika tekniker. Den praktiska nyttan av ämnet lyfts fram men på bekostnad av skönlitteratur och läsning.

Om svenska som andraspråk uppfattas som ett litteraturhistoriskt bildningsämne sätts det svenska kulturarvet $\mathrm{i}$ centrum och kända svenska författare får presentera de svenska litteraturhistoriska klassikerna i kronologisk ordning. Den svenska litteraturen făr skapa kulturella referensramar där Sverige och kärleken till det svenska fosterlandet får bilda den yttre och för alla elever gemensamma ramen. I bildningsämnet ingår både språkhistoria och litteraturhistoria. Betraktat som bildningsämne kan svenska som andraspråk därför delas in i två delar dels svensk litteratur och litteraturhistoria, dels svensk språkhistoria.

Men om innehållet i svenska som andraspråk utgår dels från elevernas egna erfarenheter, dels från deras indirekta historiska erfarenheter kan det uppfattas erfarenhetspedagogiskt ämne. Litteratur och läsning blir viktigt innehåll och litteraturen 
väljs, både utifrån de enskilda elevernas erfarenheter och förutsättningar och utifrån andra personers erfarenheter. Elevernas erfarenheter och intresse betonas. Genom litteraturläsning utvecklas deras historiska och sociala förståelse.

Betraktat som demokratiämne blir andraspråksämnets roll i samhället tydligt (Elmeroth, 2005b). Samhällets ideal är likvärdig utbildning för alla elever och om mål med svenska som andraspråk är att alla elever fullt ut ska kunna delta i samhällslivet och i samhällets samtal kan andraspråksämnet betraktas som demokratiämne. Genom ämnesinnehållet och genom att träna språket funktionellt, kan eleverna nå sådan språklig säkerhet att deltagande fullt ut blir möjligt. Språket blir på så vis ett funktionellt och demokratiskt redskap där ämnets innehåll utgår från andraspråkselevernas förutsättningar och behov.

\section{Ämnesfokus}

Ämnesfokus, hantera-var-dag, leder innehållsmässigt till kunskap som elever har nytta av i vardagen, för att förstå vardagen och samhället. Att kunna hantera vardagen kan förstås som begränsat språkbehärskande och begränsat deltagande eftersom det är en låg målsättning som inte leder till fullständigt behärskande av svenska språket.

Innehåll inom det fokus som kan betecknas svenska-språket-som-förutsättning leder till utvecklande av språkliga kompetenser i andraspråket för att lyckas i skolan och i samhället. Full språkbehärskning av andraspråket är en förutsättning för framgång både i skolan och i samhället. Detta kan uppfattas som att det är utvecklad kompetens i svenska som är förutsättningen för framgång d.v.s. är avgörande framgångsfaktor.

Med medvetenhet-för-förståelse som fokus leder andraspråksämnets innehåll till kunskap och medvetenhet om lärande. Där kan grammatikövningar eller skönlitteraturläsning $i$ funktionella sammanhang verka som instrument för språkförståelse och förståelse av lärande. Läsning kan vara ett verktyg i strävan mot att nå fullt behärskande av andraspråket dvs. förstaspråksnivå, $i$ alla de situationer som kan tänkas uppstå i livet. Nedanstående figur visar de diskuterade begreppen.

\begin{tabular}{|l|l|l|}
\hline Monokultur & $\begin{array}{l}\text { Litteraturhistoriskt bildningsämne, hantera var dag, svenska-språket- } \\
\text { som-förutsättning }\end{array}$ & $\begin{array}{l}\text { Begränsat } \\
\text { deltagande }\end{array}$ \\
\hline Multikultur & $\begin{array}{l}\text { Demokratiämne och erfarenhetspedagogiskt ämne, medvetenhet för } \\
\text { förståelse }\end{array}$ & $\begin{array}{l}\text { Deltagande } \\
\text { fullt ut }\end{array}$ \\
\hline
\end{tabular}

Figur 4. Begränsat deltagande respektive deltagande fullt ut

Genom ovanstående diskussion framträder ytterligare två utgångspunkter för tolkning. Om utgångspunkten är monokultur fokuseras färdigheter för att hantera av vardagen, svenska språket som förutsättning och det litteraturhistoriska bildningsämnet vilket leder till begränsat deltagande. Med multikultur som utgångspunkt däremot koncentreras ämnesinnehållet mot medvetenhet för förståelse där demokrati- och erfarenhetspedagogiskt fokus leder till deltagande fullt ut.

\section{Tolkningsramens båda prismor}

Utifrån ovanstående begrepp etableras två prismor vilka utgör tolkningsram när texterna analyseras. 
Det monokulturella prismat omfattar begrepp som beskriver ett ämne vilket leder till begränsat deltagande med kompenserande och likformigt innehåll.

\begin{tabular}{|c|c|c|}
\hline \multirow{3}{*}{$\begin{array}{l}\text { Begränsat } \\
\text { deltagande }\end{array}$} & Likformig & $\begin{array}{l}\text { Samma innehåll, behov och } \\
\text { förutsättningar }\end{array}$ \\
\hline & Kompensera & $\begin{array}{l}\text { Kulturell ensart, olikhet som } \\
\text { brist, svårighet } \\
\text { Litteraturhistoriskt } \\
\text { bildningsämne, hantera var dag }\end{array}$ \\
\hline & $\begin{array}{l}\text { Begränsat } \\
\text { deltagande }\end{array}$ & $\begin{array}{l}\text { Svenska språket som en } \\
\text { förutsättning }\end{array}$ \\
\hline
\end{tabular}

Figur 5. Monokulturella prismat

Genom att belysa läro- och kursplaner genom det monokulturella prismat framträder en bild av vad som erbjuds lära sett ur monokulturellt perspektiv.

Det multikulturella prismat omfattar begrepp som beskriver ett ämne vilket leder till deltagande fullt ut med kompletterande och olikformat innehåll.

\begin{tabular}{|l|l|l|}
\hline \multicolumn{1}{|c|}{$\begin{array}{l}\text { Deltagande fullt } \\
\text { Ut }\end{array}$} & $\begin{array}{l}\text { Olikformig } \\
\text { Olika innehåll, behov och } \\
\text { förutsättningar }\end{array}$ \\
\hline Komplettera & $\begin{array}{l}\text { Kulturell mångfald, olikhet som } \\
\text { resurs, möjlighet } \\
\text { Demokratiämne, } \\
\text { erfarenhetspedagogiskt ämne }\end{array}$ \\
\hline Olikformig & $\begin{array}{l}\text { Deltagande } \\
\text { fullt ut }\end{array}$ & Medvetenhet för förståelse \\
\hline
\end{tabular}

Figur 6. Multikulturella prismat

Genom att belysa läro- och kursplaner genom det multikulturella prismat framträder en bild av vad som erbjuds lära, sett ur multikulturellt perspektiv.

\section{METOD}

Texter är författade i syfte att förmedla budskap till läsare. Texter innehåller sätt att se och uppfatta från det sammanhang de tillkom i och det sammanhang de tolkas i (Bergström \& Boreus, 2000). I denna studie handlar det om att tolka och analysera budskap i texter av samma slag från olika tider men formulerade i andra sammanhang än det de tolkas i. Texterna kan beskrivas både som auktoritativa och offentliga samt benämnas olika tiders policytexter (Säfström, 1994; Östman, 1995). Genom upprepade närläsningar och genom att fokusera olika detaljer når jag djupare förståelse för texternas innebörd. Via öppenhet, dialog och frågor till texterna kan jag låta det fenomen jag vill förstå komma till tals. Textförståelsen blir på så vis en oändlig process via pendling, genom upprepad och omväxlande dialog med hela texten respektive textens delar i vad som kan kallas en förståelse- eller tolkningsspiral (Alvesson \& Sköldberg, 1994; Bengtsson, 1993; Diskay, 2002; Kvale, 1997; Molander, 2003). Genom att ställa frågor till de olika texterna som belyser hur de förhåller sig till varandra blir det möjligt att visa på förändringar, brott och dubbla spår. 
Eftersom min undersökning inriktas mot att studera hur ett fenomen skrivs fram i olika tider i samma sorts dokument studeras texters intertextualitet. Genom upprepad och fördjupad läsning samt med hjälp av de båda prismorna belyser jag och tolkar de olika texterna ur olika perspektiv. Följande texter analyseras: Lgr62 (Kungliga Skolöverstyrelsen, 1962), Lgr69, (Skolöverstyrelsen, 1969), Lgr69 (Skolöverstyrelsen, 1969), Lgr80 (Skolöverstyrelsen, 1980), Lpo94 (Utbildningsdepartementet, 1994) och kursplaner som behandlar svenska som andraspråk (Skolöverstyrelsen, 1969; 1973; 1980; 1985:4; Skolverket, 1996; 2000).

\section{RESULTAT OCH ANALYS AV I LÄROPLANER FORMULERADE IDEAL}

Frågeställningen vilka i läroplaner formulerade ideal svenska som andraspråk omfattas av ligger till grund för första analyssteget där läroplanerna belyses genom det monokulturella och det multikulturella prismat.

\section{Likformig/olikformig}

När den gemensamma grundskolan infördes 1962, formulerades likvärdig utbildning i en skola för alla (Kungliga Skolöverstyrelsen, 1962). Alla barn, oavsett bakgrund och var i landet de bodde, garanterades samma möjligheter till likvärdig utbildning för ökad jämlikhet (SOU: 1971:51; SOU 1974:69).

Ett av skolans syften är att - så långt det över huvud är möjligt - bereda alla uppväxande, oberoende av bostadsort och andra yttre villkor, reell tillgång till lika utbildningsmöjligheter. Grundskolan ska därför ge dem en i huvudsak gemensam utbildning... (Skolöverstyrelsen, 1969, s. 11)

... utbildningen inom varje skolform skall vara likvärdig, oavsett var i landet den anordnas. (Utbildningsdepartementet, 1994, s. 6)

Då den likvärdiga skolan förutsatte att alla barn var lika och brister i bakgrund ansågs kunna utjämnas med likformigt utformad utbildning kan utbildningen förstås vara både monokulturell och förtryckande. Förändringar har dock skett (Englund, 1995; 1999; Berg, 2003). Betydelsen av begreppet likvärdig var annorlunda i grundskolans första läroplan jämfört med den nu gällande. Likvärdig utbildning/likformad utbildning med likadant innehåll enligt både Lgr62 och Lgr69, har omformulerats till likvärdig/individuell och olikformad i Lgr80 och Lpo94.

En likvärdig utbildning innebär inte att undervisningen skall utformas på samma sätt överallt eller att skolans resurser skall fördelas lika. Undervisningen skall anpassas till varje elevs förutsättningar och behov. (Utbildningsdepartementet, 1994, s.6)

Dessa båda läroplaner framskriver på ett tydligt vis att den likvärdiga utbildningen ska vara olikt utformad på grund av att elever är olika. Likvärdig utbildning är olikformad.

I grundskolans första läroplan, Lgr62, fanns inga speciella skrivningar kring undervisning av elever med svenska som ett andraspråk. Detta kan förstås som att de förväntades assimileras in i skolan och samhället. Inte heller i grundskolans nu gällande läroplan, Lpo94, fanns till en början speciella formuleringar för elevgruppen. Genom 
ordinarie undervisning förväntades de ingå i kamrat- och skollivet. Det som uttrycktes, eller snarare inte uttrycktes, var den för givet tagna uppfattningen att alla barn var likadana och omfattades av det svenska språket, den svenska kulturen och värdegrunden. Med utgångspunkt $\mathrm{i}$ tidigare begreppsdiskussion kan sägas att både grundskolans första och nu gällande läroplan visade likgiltighet för elever med svenska som ett andraspråk trots skrivningar om alla barns rätt och skyldighet att delta $\mathrm{i}$ grundskolans undervisning.

\section{Kompensera/komplettera}

De samhällspolitiska formuleringarna kring rätten att behålla och utveckla olika språk (Prop.1975:26) formulerar ett kompletterande sätt att se på utbildning i termer av att andraspråket uppfattas vara ett komplement till förstaspråket samt att olika språk och kulturer anses komplettera varandra. Grundskolans första läroplan Lgr62 saknade speciella formuleringar. Sett ur tolkningsramens monokulturella prisma kan de utbildningsideal, vilka jämställer likvärdig utbildning med samma utbildningsbehov, sägas vara formulerat av ett samhälle som genom läroplaner uttrycker uppfattningen att grundskolans utbildning kan kompensera elever för det som uppfattas vara deras brister. Alla kan på så vis nå samma mål och ges likadana möjligheter till fortsatt utbildning. I senare läroplaner, Lgr80 och Lpo94, är uttrycket delvis förändrat genom att formulerade ideal tydligare framskriver förståelse för barns olika kompetenser och förutsättningar.

Skolans insatser skall planeras och krav ställas utifrån varje barns aktuella förutsättningar. (Skolöverstyrelsen, 1980, s. 14)

Om utbildningen kompletterar elevers kompetenser kan en likvärdig skola för alla bli verklig. Sett genom det multikulturella prismat kan vad som uttrycks i Lgr80 och Lpo94 förstås vara utbildning vilken respekterar alla, ser elevers varierande förutsättningar, tidigare kunskaper och erfarenheter som resurser vilka berikar och kompletterar varandra. Detta beskriver en skola som förbereder för ett multikulturellt samhälle där variation i kompetens kompletterar.

\section{Begränsat deltagande/deltagande fullt ut}

Läroplanerna från Lgr62 till och med Lpo94 uttrycker alla barns rätt till skola och utbildning.

Alla skall, oberoende av kön, geografisk hemvist och sociala och ekonomiska förhållanden, ha lika tillgång till utbildning i grundskolan. (Skolöverstyrelsen, 1980, s. 14)

De framskriver också på olika vis att undervisningen ska ha sin utgångspunkt i elevers förutsättningar och att den ska fostra till samhällsmedborgare.

När skolan utför sin fostrargärning, måste den därför se till, att arbetet väl anpassas icke blott till den enskildes utan också till samhällets utveckling. (Kungliga Skolöverstyrelsen, 1962, s. 13)

Härigenom formulerar alla läroplanerna en intention om alla elevers deltagande i både skola och samhälle. Dock har denna intention uttryckts på skiftande vis i de olika läroplanerna. Trots att det uttrycktes att undervisningen skulle anpassas med hänsyn till 
eleverna fanns inga skrivningar som speciellt kan sägas gälla elever med svenska som ett andraspråk varken i 1962 eller 1994 års läroplaner. När formuleringar saknas kan det tolkas som uttryck för en utbildning där alla antas ha svenska som förstaspråk. Genom visad likgiltighet, vilket tidigare diskuterats $i$ termer av avsaknad av formuleringar, framträder ett samhälle som inte bjuder in elever med annat ursprung än svenskt till deltagande. När elevgruppen inte var omnämnd kan det ses som att den inte var medräknad. Genom att inte vara medräknad kan undervisningens syfte sägas ha varit begränsat kunnande och deltagande och fostran till begränsat deltagande $\mathrm{i}$ samhället.

I Lgr69 fanns formuleringar som uttryckte en ökad medvetenhet för olika elevers behov men skrivningarna uttalade också ett samhällsvärde som var att utbilda för begränsat deltagande eftersom ett fostransuppdrag med utgångspunkt i samhällets behov starkt betonades.

... förbereda sig för sin roll som aktiv medborgare i morgondagens samhälle, som betydligt mer än det nuvarande kommer att kräva samverkan och solidaritet mellan människor. (Kungliga Skolöverstyrelsen, 1962, s. 13, Skolöverstyrelsen, 1969, s. 10)

I och med 1975 års invandrarpolitiska beslut gällande jämlikhet, valfrihet och samverkan förändrades skolans fostransuppdrag (Prop.1975:26). Dessa samhällspolitiska mål fick genomslag i läroplansformuleringarna på så vis att fostransuppdraget förändrades från individens övning inför sin framtida begränsade medborgarroll, Lgr62 och Lgr69, till att Lgr80 och Lpo94 uttryckte betydelsen av att skolan i sitt fostransuppdrag samarbetade med hemmen för att förbereda eleverna för framtida roller i samhället.

... i samarbete med hemmen främja elevernas utveckling till ansvarskännande människor och samhällsmedlemmar. (Utbildningsdepartementet, 1994, s. 7)

Detta kan förstås som att skolans utbildning i ökad utsträckning syftade till deltagande fullt ut i det svenska samhället eftersom individens behov och önskemål i större utsträckning var av betydelse för utbildningens innehåll. Samtidigt begränsades deltagandet $\mathrm{i}$ ett multikulturellt samhälle eftersom skolan fortfarande avsåg att fostra och påverka eleverna att vilja omfattas av den svenska demokratins grundläggande värderingar. Detta talar dessutom både mot målet om jämlikhet och mot målet om valfrihet. Jämlika medborgare deltar fullt ut i det samhälle de lever i. Men då fostransuppdraget fortfarande är uttryckt som fostran i svensk demokrati, västerländsk humanism och kristen tradition har eleverna ingen valfrihet. Därför leder utbildningen formulerad i Lgr80 och Lpo94 inte heller till fullständigt deltagande för alla.

\section{Konklusion}

När Lgr62, Lgr69, Lgr80 och Lpo94 analyseras genom det monokulturella prismat åskådliggörs en utbildning som syftar till fostran $i$ enlighet med rådande samhällsvärden, att alla elever ska nå gemensamma mål oavsett språklig och kulturell bakgrund. Alla fyra läroplanerna Lgr62, Lgr69, Lgr80 och Lpo94 utgår från att svenskt perspektiv och svenska värderingar. Utbildningen är med andra ord tänkt att forma och fostra i det gemensamma svenska med likformig undervisning som kompenserar brister för begränsat deltagande. När grundläggande värden formuleras som kristen tradition 
och västerländsk humanism (Lpo94) framskrivs värden gällande vad som anses viktigt att barnen lär sig sett ur ett monokulturellt perspektiv.

Om texterna i stället belyses genom det multikulturella prismat visar Lgr80 och Lpo94 en utbildning som är riktad mot att stärka och acceptera elevers olikheter, mot främjande av olika individers behov och förutsättningar samt ömsesidig respekt. Alla är lika värda eftersom undervisningens innehåll ska utgå från elevers olika behov och förutsättningar. De invandrarpolitiska målen har fått genomslag genom att Lgr80 och Lpo94 uttrycker värdet av att individen själv får avgöra $i$ vilken mån hon vill komplettera ursprungskulturen och förstaspråket samt att individens behov ska vara utgångspunkt. På detta sätt formuleras dubbla spår eftersom den utbildning som formuleras i Lgr80 och Lpo94 också är olikformig och kompletterande för deltagande fullt ut. Läroplanerna uttrycker härigenom centrala värden gällande vad som är viktigt att barnen lär sig sett ur ett multikulturellt perspektiv.

Analysen visar på detta sätt att läroplanerna från Lgr62 till och med Lpo94 uttrycker förändring, brott och dubbla spår genom motsägelsefulla ideal. Förändringen innebär en utveckling från likgiltighet i Lgr62 till begränsat deltagande i Lgr69 och i Lgr80. Men i och med att nu gällande läroplan, Lpo94, först inte innehöll speciella formuleringar gällande andraspråkselevers utbildning bröts denna utveckling genom återgång till likgiltighet för elevgruppens speciella språksituation och behov. Genom att Lpo94 kompletterats uttrycks vad som kan kallas dubbla spår och motsägelse fulla ideal i nu gällande läroplan eftersom elevers olikheter, olika behov och medvetenhet om andraspråkselevers behov av språkutvecklande insatser formulerades. De motsägelsefulla idealen kan å ena sidan beskrivas som bevarande av gemensamma värden genom likformad utbildning, å andra sidan kan de beskrivas som bejakande av olikhet genom olikformad utbildning där olika elevers behov avgör hur undervisningen utformas. Tidigare beskrivna återgång till visad likgiltighet visar på brott mot de invandrarpolitiska målen, valfrihet, jämlikhet och samverkan då formuleringar respektive avsaknad av formuleringar talar om vad som är samhälls- och utbildningspolitiskt viktigt. Avsaknad av formuleringar kan sägas visa att likformighet var viktigare än olikformighet.

Nedanstående figur visar läroplaner från 1969 till och med 1994 sett ur två perspektiv. De olika läroplanerna är markerade med L.

\begin{tabular}{|c|c|c|c|c|}
\hline Multikultur & & & $\mathrm{L}$ & $\mathrm{L}$ \\
\hline Monokultur & $\mathrm{L}$ & $\mathrm{L}$ & & L \\
\hline Läroplaner & 1962 & 1969 & 1980 & 1994 \\
\hline
\end{tabular}

Figur 7. Mono- och multikulturella uttryck, brott och dubbla spår i läroplaner från 1962 t.o.m. 1994

Figuren visar förändrade utbildningsideal från Lgr62 till Lgr80, brott mot denna utveckling och dubbla spår i Lpo94. 


\section{RESULTAT OCH ANALYS AV I KURSPLANER KONKRETISERADE IDEAL}

Frågeställningen vilka i kursplaner konkretiserade ideal andraspråk omfattas av ligger till grund för andra analyssteget där kursplanerna belyses genom det monokulturella och det multikulturella prismat.

\section{Likformig/olikformig}

Från 1969, 1980/1985 och 1996/2000 finns särskilda formuleringar kring andraspråk i form av kursplaner. Någon kursplan för ämnet svenska som andraspråk fanns inte när nu gällande läroplan, Lpo94, togs i bruk beroende på att det förslag som fanns var annorlunda utformat $\mathrm{i}$ jämförelse med andra kursplaner. Förslaget var utarbetat utifrån ämnets och andraspråkselevers speciella språksituation. En kursplan, likformad med andra ämnes kursplaner, kom dock att gälla från 1996. Den reviderades och skärptes 2000 på så vis att uppnåendemålen för år nio inte tog hänsyn till hur lång tid elever varit i kontakt med andraspråket.

Mål som eleverna skall ha uppnått i slutet av femte skolåret eller efter en första del i undervisningen. (Skolverket, 2000, s. 105)

Mål som eleverna skall ha uppnått i slutet av det nionde skolåret. (Skolverket, 2000, s. 106)

I en skola där alla erbjuds likformig utbildning kan utgångspunkten förstås vara att alla barn har samma förutsättningar, samma förstaspråk och behov av samma svenskundervisning.

Elever med olika modersmål kan utan olägenhet undervisas gemensamt i svenska.

(Skolöverstyrelsen, 1973, s. 8)

Utgångspunkt kan också ses som att skolans ordinarie undervisning kan ge alla likformiga förutsättningar till fortsatt utbildning. I en likformad utbildning behövs inte några speciella formuleringar kring ämnesmål och ämnesinnehåll i form av kursplaner. Enligt ovanstående resonemang är avsaknad av kursplan att betrakta som diskriminerande eftersom den visar likgiltighet. Även kursplanerna från 1969 och 1980 (stöd och främmande språk), där utgångspunkten var elevers brist på kunskaper i svenska och brist på kunskap om den svenska kulturen, är att betrakta som diskriminerande.

Undervisning som syftar till funktionellt språkbehärskande av andraspråket uttrycks i komplementet från 1985 och i kursplanerna från 1996/2000 genom att utvecklande av tvåspråkighet var formulerat som ämnets syfte. Svenska språkets betydelse för kunskapande och kommunikation framskrivs klart i nu gällande kursplan från 2000.

Det svenska språket har en nyckelställning i skolarbetet. Genom språket sker kommunikation och samarbete med andra. (Skolverket, 2000, s. 102)

Kursplanen uttrycker att skolan genom undervisning i svenska som andraspråk ska ge eleverna denna kunskap. Ämnet har ett trefaldigt mål i nu gällande kursplan som är att lära sig om språket, att lära sig på språket och att genom språket lära känna svenskt kulturarv. Detta visar på andraspråkets och andraspråkselevernas speciella situation när det gäller att både utveckla och kommunicera på svenska. Andraspråksundervisning 
organiserad olika, med olika innehåll utifrån elevers olika behov stämmer väl med de uttalade samhällsmålen jämlikhet, valfrihet, samverkan och en skola där alla är likvärdiga. Om andraspråksundervisningens innehåll utgår från tid i kontakt med målspråket blir innehållet olikformigt med utgångspunkt i elevers olika behov och förutsättningar. Valfrihet förutsätter att andraspråkseleverna erbjuds möjligheter att välja i vilken mån de vill vidareutveckla sitt förstaspråk och hur det svenska ska integreras dvs. i vilken mån de vill vara likformiga respektive olikformiga. Flerspråkighet och mångkulturalitet kan i detta sammanhang ses som olikformigt $\mathrm{i}$ jämförelse med det enhetliga och likformiga, monokulturellt svenska.

\section{Kompensera/komplettera}

Med stöd av tidigare resonemang fungerar, enligt svensk tradition, den jämlika skolan och specialpedagogisk undervisning kompenserande. Detta bygger på uppfattningen att skolan kan kompensera barns och hems brister genom undervisning. Traditionen av stöd och kompensation som har förts vidare i andraspråksundervisningen kan härledas till skrivningarna i första kursplanen (Skolöverstyrelsen, 1969) där benämningen är just stöd.

Stödundervisningen har till mål att ... // ... elementär undervisning i att förstå och tala svenska samt orientering i den nya miljön... (Skolöverstyrelsen, 1973, s. 8)

De framskrivna ämnesmålen i den första kursplanen kan ses som uttryck för ett monokulturellt samhälles formulerade värdegrund. De visar på ett samhälle där utbildning handlar om att kompensera elevers bristande kunskaper om de svenska värdena, den svenska kulturen och det svenska språket. Med stöd i tidigare begreppsdiskussion kan detta leda till marginalisering, assimilering och känslor av utanförskap. Eftersom andraspråkseleverna skulle undervisas inom ramen för ordinarie undervisning, enligt kursplanerna från 1969 och 1980, uttrycks kompenserande undervisning med syfte att andraspråkselever ska bli mer monospråkliga och monokulturella. Detta kan sägas vara det mest normala i den svenska skolan men stämmer dåligt med målen om jämlikhet och samverkan. Det kan i stället ses som förtryck i form av likgiltighet inför enskilda elevers förutsättningar och behov. I en skola för alla kan likgiltighet för elevers behov och tidigare erfarenheter inte ses som likvärdig undervisning. För att skolan ska vara likvärdig måste i stället alla individer erbjudas den obligatoriska skolans utbildning organiserad i kompletterande syfte. Det kan också ses i ljuset av andraspråkselevers svenskkunskaper kan ses som en brist samt att invandrarbakgrund kan ses som ett problem. Genom komplementet till ämneskursplanen från 1985 har inriktningen ändrats då texten uttrycker ett kompletterande synsätt.

Andraspråksinlärningen i svenska pågår mot bakgrund av att eleverna redan har och samtidigt ska utveckla sitt förstaspråk. (Skolöverstyrelsen, 1985:4, s. 8)

Kursplanerna från 1996/2000 är däremot motsägelsefullt formulerade eftersom de uttrycker både kompenserande och kompletterande innehåll. Genom det svenska språket och läsning av den svenska skönlitteraturen ska eleverna förstå den svenska värdegrunden samt skillnaden mellan ursprungskulturens värdegrund och den svenska. Kursplanen uttrycker också att eleverna genom ämnets innehåll ska

... förstå svensk skönlitteratur och svensk kultur... (Skolverket, 2000, s. 103). 
När eleverna ska förstå det svenska samhället och den svenska värdegrunden genom läsning av svensk litteratur framträder en monokulturell utbildning där skolan ska kompensera elevers bristande kunskaper om det svenska. Att nå full språkbehärskning, att förstå sig själv och andra samt svensk kultur och andra kulturer genom lustfylld läsning talar däremot ur ett multikulturellt perspektiv där alla är lika mycket värda, ömsesidigt respekterar varandra och variation upplevs komplettera. Förutsättning för detta är dock att den lustfyllda läsningens litteraturval utgår från ett kompletterande synsätt med litteratur från enskilda elevers ursprungskulturer. Om litteraturen väljs utifrån svensk litterär kanon, eller med utgångspunkt i andra kulturer i största allmänhet, kan synsättet i stället förstås som kompenserande.

\section{Begränsat deltagande/deltagande fullt ut}

Andraspråksämnets innehåll fokuserat på språkövningar, enkelt vardagsspråk och begränsat deltagande har, över tid, förändrats till innehåll som fokuserar förstaspråksnivå i andraspråket vilket här tolkas som deltagande fullt ut.

I den första undervisningen, betecknad stöd (1969) och delvis också senare undervisning betecknad svenska som främmande språk (1980) var fokus riktat mot isolerad färdighetsträning. Här dominerade hantera-var-dag fokus med orientering i den svenska miljön. Målet var att eleverna skulle kunna förstå enkelt vardagsspråk respektive begrepp inom olika ämnesområden och delta $i$ den ordinarie klassrumsundervisningen. Innehållet uttrycker, i ämnets första kursplaner, fokus riktat mot ett bildningsämne med betoning på svenskt kulturarv för deltagande i det svenska monokulturella samhället. Kursplanerna (1969/1980) beskriver således utbildning för begränsat deltagande. Full språkbehärskning däremot innebär att behärska både förstaoch andraspråket dvs. tvåspråkighet och att kunna delta fullt ut både i kamratliv och i samhällsliv. Detta framskrivs i kompletteringen (1985) och kursplanerna (1996/2000).

Även i nu gällande kursplanen framträder vad Malmgren (1996), Elmeroth (2005b) och Östman (1995) beskriver som olika innehåll och fokus för ämnet vilket innebär att olika bilder kan ges med hjälp av olika ämnesbeskrivningar. Bilderna visar att kursplanens uttrycker både är motsägelsefullt och bryter mot tidigare uttryckta ideal vilket var kunskaper för att kunna hantera-var-dag. Nu gällande mål för andraspråket framskrivs exempelvis vara att lära sig svenska för att komma in i kamratlivet och delta $\mathrm{i}$ samhällslivet på samma villkor som elever med svenska som förstaspråk.

... tillägna sig en sådan språkbehärskning att de med fullt utbyte kan tillgogogöra sig utbildning... (Skolverket, 2000, s. 102)

Detta kan förstås som fokus mot ett demokratiämne, där full behärskning av det svenska språket, dvs. förstaspråksnivå i andraspråket, uttrycks som mål att nå. Demokratiämnet omfattar också språkfärdigheter som att rätt kunna hantera språkets form i olika situationer, att vara medveten om språkets betydelse för att förstå sig själv och andra och att känna till språklig variation. Detta förutsätter att eleverna får använda språket "... i olika sammanhang och kring ett meningsfullt innehåll." (Skolverket, 2000, s. 104) och får tillfälle att träna form i sammanhang, genom läsning, skrivning och i dialog utifrån enskilda elevers behov och tidigare erfarenheter. Detta kan sägas beskriva ett erfarenhetspedagogiskt ämne vilket leder till delande av erfarenheter. Som 
demokratiämne uttrycks på så vis ämnets roll i samhället i form av utbildning vilken leder till att fullt ut kunna delta i ett svenskt samhällsliv.

I kursplanen från 2000 formulerat innehåll kan också sägas beskriva ämnet som färdighetsämne och bildningsämne (Malmgren, 1996).

... språket är en förutsättning för elevernas fortsatta liv och verksamhet.

(Skolverket, 2000, s. 102)

Med fokus på svenska-språket-som-förutsättning där träning av svensk grammatik, läsning av svensk litteratur och skrivande på svenska prioriteras ska eleverna "... förstå svensk skönlitteratur och svensk kultur..." (Skolverket, 2000, s. 103). Genom läsning ska eleverna också lära känna litteratur och kultur från andra delar av världen. Med stöd i tidigare begreppsdiskussion beskriver detta ett ämne vilket syftar till att eleverna ska se på övriga världen med svenska glasögon. Bildningsämnet svenska som andraspråk kan därmed förstås syfta till kunnande och deltagande i ett monokulturellt Sverige.

Vad som inte omnämns är läsning av olika sorts texter skrivna på förstaspråket samt förståelse för ursprungskulturens litteratur och kunskap om ursprungslandets författare. Detta innebär att elevernas tidigare erfarenheter inte tas tillvara. Således kan läsning av svensk litteratur och litterär kanon inte beskrivas som varande erfarenhetspedagogiskt ur ett multikulturellt perspektiv syftande till deltagande fullt ut. Om läsningen däremot tar sin utgångspunkt i förstaspråken kan ämnet beskrivas som erfarenhetspedagogiskt och multikulturellt. I nu gällande kursplan, 2000, talas det vidare om att lära sig förstå både sig själv, andra människor och hur det egna andraspråkslärandet går till för att genom detta kunna både få och befästa kunskaper.

... utveckla förståelse för varför människor skriver och talar olika. (Skolverket, 2000, s. 103)

Detta kan ses som exempel på att använda språk/uppfatta språkanvändning som verktyg för att underlätta lärande samt för att förstå sitt och andras lärande vilket är fokus på medvetenhet-för-förståelse. Det betyder även förståelse för och kunskap om tvåspråkighet och multikulturalitet. Fokus på medvetenhet-för-förståelse inbegriper medvetenhet och kunskap som syftar till deltagande fullt ut i ett multikulturellt Sverige. Svenska-språket-som-förutsättning för skolframgång och fortsatt liv i svenska samhället är ett innehåll som är otydligt förmedlat eftersom det kan uppfattas uttrycka både begränsat deltagande och deltagande fullt ut. Detta är beroende av om innehållet fokuserar enbart andraspråket som förutsättningen för framgång och deltagande ur ett monokulturellt perspektiv. Det är också beroende av om fokus riktas mot förstaspråket som en av förutsättningarna för framgång och deltagande fullt ut ur ett multikulturellt perspektiv.

\section{Konklusion}

Analys av kursplanerna från 1969, 1980/1985 och 1996/2000 med hjälp av det monokulturella prismat åskådliggör ett ämne vilket syftar till att kompensera elever för deras brister. Den kompenserande stödundervisningen och främmandespråksundervisningen syftade till begränsat kunnande och begränsat samhällsdeltagande. I nu gällande kursplan framskrivs fostran i likformighet genom studium av svensk kultur och svenskt kulturarv. Behärskande av svenska som 
andraspråk uttrycks som förutsättning för framgång både i skolan och i samhällslivet i övrigt. Belyst genom det monokulturella prismat förstås skolämnet svenska som andraspråk varande kompenserande och likformigt ledande till begränsat deltagande genom fostran i det sammanhållande och gemensamma kulturarvet, sett ur ett monokulturellt perspektiv.

Analysen visar också ett ämne vilket utbildar och fostrar inom en multikulturell ram. Detta är uttryckt i komplementet från 1985 och i kursplanerna från 1996/2000. Tolkning genom det multikulturella prismat visar att ämnet även syftar till fullt deltagande i skola och samhällsliv genom att eleverna ska utvecklas till tvåspråkiga individer. Detta är både olikt och multikulturellt i jämförelse med enspråkiga elever. Analysen visar också att andraspråkselever ska komplettera förståelsen av det egna sättet att lära med förståelse för och medvetenhet om olika individers skiftande behov och förutsättningar samt kunskap om andra kulturer än den egna. Skolämnet svenska som andraspråk är i dessa avseenden kompletterande och olikformigt ledande till deltagande fullt ut genom fostran i respekt för att människor är olika sett ur ett multikulturellt perspektiv.

Analysen visar således, med stöd i tidigare diskuterade begrepp, att kursplanerna från 1969 till och med 2000 uttrycker förändring samt brott och dubbla spår med motsägelsefulla ideal. Med stöd i de båda prismorna kan sägas att det mellan 1969 och 1980 har varit förändring i riktning från monokultur mot multikultur. Kursplanen från 1980 kompletterades 1985 genom förändring av ämnesbeteckning när svenska som främmande språk (begränsat deltagande) ändrades till svenska som andraspråk (deltagande fullt ut). Mellan 1969 och 1985 har följaktligen en förändring ägt rum från likformighet och enspråkighet som norm, till olikformighet där andraspråksutveckling ansågs främja barnets totala utveckling. Norm att andraspråket både berikar och kompletterar. Förändringen kan också sägas vara från begränsat kunnande och deltagande till fullt behärskande av andraspråket och en intention om att fullt ut kunna delta i samhällslivet.

Brott mot denna förändring kan dock sägas ha skett i form av en tillbakagång mot monokultur och likgiltighet för olika behov och förutsättningar eftersom det först inte fanns någon kursplan för ämnet när den nu gällande läroplanen (Lpo94) togs i bruk. Brottet innebär också dubbla spår genom motsägelsefulla formuleringar i kursplanerna från 1996/2000. Analysen visar ett monokulturellt bildningsämne där innehållet till övervägande del erbjuder lärande av svensk kultur och svensk tradition där behärskande av svenska språket är norm och ses som en förutsättning för att nå framgång och deltagande i samhällslivet. Men analysen visar också ett multikulturellt ämne som genom skrivningar om allas lika värde samt formuleringar kring att undervisningen och ämnets innehåll ska leda till kunskap om andra kulturer och utgå från elevernas tidigare erfarenheter. Att behärska olika språkliga situationer är också en del av ett demokratiämne vilket visar på skolämnets roll i samhället. 
Nedanstående figur visar analyserade kursplaner från 1962 till och med 2000 sett ur två perspektiv. De olika kursplanerna är markerade med K, avsaknad av kursplan är markerat med streck (--).

\begin{tabular}{|l|lllllll|}
\hline Multikultur & \multicolumn{1}{c}{} & & & K & & K & K \\
& & & K & & & & \\
& & & & & & K & \\
\hline Monokultur & -- & K & & & -- & & K \\
\hline Kursplaner & 1962 & 1969 & 1980 & 1985 & 1994 & 1996 & 2000 \\
\hline
\end{tabular}

Figur 8. Mono- och multikulturella uttryck, bott och dubbla spår i kursplaner från 1962 t.o.m. 2000

Figuren visar förändring i uttryckta ideal från monokultur $(1962,1969)$ till multikultur (1980/1985). Figuren visar också brott mot utveckling samt dubbla spår i kursplanerna $1996 / 2000$.

\section{FÖRÄNDRING, BROTT OCH MOTSÄGELSEFULLA IDEAL}

Analysen visar att de invandrarpolitiska målen omfattar den obligatoriska skolan. Detta innebär att alla har rätt att behålla och utveckla sitt förstaspråk och att alla har rätt till utbildning. Ömsesidig respekt och individens valfrihet är viktiga komponenter för integration. Därför speglar syftet att fostra och överföra grundläggande värden motsägelsefulla ideal. Vikten av individens valfrihet och behov betonas samtidigt med det gemensamhetsskapande och enhetliga. Både individuella och sammanhållande värden är viktiga att överföra till eleverna. Samtidigt innebär avsaknaden av formuleringar att likvärdig utbildning är det samma som likformad utbildning med utgångspunkt att alla har samma behov och förutsättningar samt att skolans undervisningsinnehåll kan kompensera elevers brister.

Med nedanstående figur sammanförs de analyserade läro- och kursplanerna. Läroplaner är markerade med L, kursplaner med K medan avsaknad av kursplan är markerat med streck (--).

\begin{tabular}{|l|lllllll|}
\hline Multikultur & & & L & K & L & K & K \\
& & & K & & & & \\
& & & & & & & \\
Monokultur & L -- & K & & & L -- & K & K \\
\hline Läro- och kursplaner & 1962 & 1969 & 1980 & 1985 & 1994 & 1996 & 2000 \\
\hline
\end{tabular}

Figur 9. Förhållandet mellan läro- och kursplaner från 1962 t.o.m. 2000

Figuren ovan visar förändring över tid, brott mot förändring och motsägelsefulla ideal. Dessa motsägelsefulla ideal leder till spänningsförhållanden mellan nu gällande läroplan (Lpo94) och de nu gällande kursplanerna (1996/2000). Individens valfrihet, allas lika värde och möjligheten att påverka har formulerats $\mathrm{i}$ den nu gällande läroplanen. Men med utgångspunkt i det monokulturella prismats begrepp formuleras $\mathrm{i}$ kursplanen 2000 innehåll ledande till likformighet med majoritetskulturen och begränsat behärskande av samhällets majoritetsspråk. Formuleringarna utgör brott mot 
i läroplanen uttryckta ideal om utbildning för deltagande fullt ut. Motsägelsefullt är också ett ämne som inriktas mot litteraturhistorisk bildning där det svenska ensidigt lyfts fram. Samtidigt synliggörs ett erfarenhetspedagogiskt demokratiämne där enskilda elevers erfarenheter och behov är utgångspunkt, fokus riktas mot medvetenhet för förståelse.

\section{AVSLUTANDE REFLEKTION}

Nationella mål, värderingar och principer håller samman den nationella grundskolan. Att olika tider framför olika idéer kring utbildning speglar maktförhållanden och spänningsförhållanden mellan vad som ansetts viktigt att lära. Dessa spänningsförhållanden leder till förändringar och variation i utbildningsinnehåll. Sett i ljuset av vad Englund (1986; 1995; 1998; 1999; 2005) och Lundgren (1979/1989; 1984) skriver framstår både nu gällande läroplan och kursplan för ämnet svenska som andraspråk som en blandning av klassisk-, moralisk-, rationell- och medborgerlig läroplanskod. De som ägt makt att formulera texterna har uttryckt ett innehåll avsett att bilda och fostra enligt svenska värden och normer. Men då den obligatoriska skolans värdegrund uttrycks i termer av kristen tradition och västerländsk humanism inkluderas somliga medan andra exkluderas. Samtidigt ska skolan fostra för deltagande i det demokratiska samhället utifrån individers olika förutsättningar och behov.

Svenska som andraspråk betraktat som bildningsämne med fokus på svensk litteratur och svenskt kulturarv placerar ämnet inom fältet klassisk läroplanskod där bildning, humaniora och kulturarv är viktiga delar. Enligt nu gällande kursplan ska eleverna genom språket bli medvetna om sitt och andras lärande och språket ska fungera som ett verktyg för fortsatt lärande. Detta kan sägas beskriva ett ämnesinnehåll som omfattas av de bärande principerna för rationell läroplanskod med innehåll användbart både för individen och för samhället. Lpo94 och kursplanerna 1996/2000 uttrycker dessutom ett innehåll som omfattas av både medborgerlig och moralisk läroplanskod då innehållet avser att överföra grundläggande demokratiska värderingar, kristen tradition och västerländsk humanism i sin strävan att fostra eleverna till medborgare. Svenska som andraspråk sett som demokratiämne visar ämnets roll i samhället. I kursplanen från 2000 beskrivs (svenska) språkets nyckelställning och förutsättning för framgång i skolan, fortsatt liv och verksamhet i samhället. Det beskrivs också som centralt att eleverna genom ämnet lär sig förstå svensk kultur och svensk värdegrund. Andraspråkseleverna erbjuds lärande om den svenska kulturen och förståelse för det svenska genom svenska språket. Visserligen framskrivs också värdet av att förstå andra kulturer, men med det svenska både som utgångspunkt och som norm. Eleverna erbjuds lära sig både vad det svenska samhället förväntar sig av dem och vad de kan förvänta sig av samhället. Andraspråksämnet kan därför förstås erbjuda lärande som syftar till bevarande av monokultur och svensk värdegrund. Erbjudandet är likformigt och kompenserande ledande till begränsat deltagande. Ämnets roll i samhället är i huvudsak bevarande av rådande ordning varför det som är olikt denna ordning utesluts från samhörigheten.

Av jämlikhetsskäl kan skolans mål inte sättas lägre för andraspråkselever än för förstaspråkselever, skriver Tingbjörn (1981). Men andraspråksämnet kan uppfattas vara både en segregerande och en kompenserande verksamhet för elever med annat förstaspråk än svenska och eleverna kan uppfattas vara svagpresterande, skriver 
Myndigheten för skolutveckling (2004). Svenskheten och det svenska språket utgör norm och utgångspunkt för skolans undervisning. Svenska som andraspråk kan upplevas som problematiskt och som en avvikelse i förhållande till det normala som är svenska som förstaspråk. Då den obligatoriska skolans utbildningsmål är likvärdig utbildning för alla och fostran till ömsesidig respekt för olika individers lika värde borde också alla elever vara medräknade i skolans gemenskap. Den jämlika skolans förändring och utveckling kan diskuteras med utgångspunkt i vad Abbasian (2003) och Parszyk (199) skriver om segregation, utanförskap eller tillhörighet. Att inte vara medräknad som deltagare i skolans gemenskap, att vara utesluten och inte innesluten är en form av segregering. Att inte fullt ut kunna delta i skolans verksamhet innebär både diskriminering och utanförskap. Jämställdhet och ömsesidig respekt däremot är förutsättningar för integration och deltagande fullt ut både i skolan och i samhället. För att elever ska integreras krävs möjlighet att delta fullt ut både $\mathrm{i}$ skolan och $\mathrm{i}$ samhällslivet, vilket i sin tur både innebär och leder till en multikulturell skola och ett multikulturellt samhälle.

\section{Slutligen}

Denna studie gör inte anspråk på att ge en fullständig bild av grundskolans styrdokument. Men min studie, där analysen är genomförd med utgångspunkt i studiens teoriram, utgör ett inlägg i diskussionen kring andraspråkselevers skolsituation och andraspråksämnet i grundskolan genom att spegla en begränsad del av ett stort sammanhang.

Det är inte förvånande att förvirring och oklarheter råder kring andraspårksämnets målgrupp, mål och innehåll. En multikulturell skola måste främja alla elevers rätt att dels använda olika språk, dels möta kulturell och språklig variation. Men elever med svenska som ett andraspråk erbjuds varken likvärdig utbildning eller utbildning som möjliggör uppnående av grundskolans mål att nå. En av anledningarna till att andraspråkselever erbjuds olikvärdig utbildning är att undervisningen ofta bedrivs $\mathrm{i}$ form av stödundervisning och genomförs av obehöriga lärare vilket både Elmeroth (2005a), Tingbjörn (2000) och Myndigheten för skolutveckling (a.a.) belyser. Således är det problematiskt att många av de lärare som undervisar i svenska som andraspråk saknar ämneskompetens, att andraspråksundervisning inte ordnas alls (Lgr62; Lpo94) eller fortfarande organiseras som stödundervisning (Lgr69).

Enligt nu gällande kursplan är ämnets tänkta målgrupp elever med kulturell och språklig bakgrund annan än svensk som därför kan ha svårt att delta i ordinarie undervisning. Genom undervisning i svenska som andraspråk, genom att träna språket i alla ämnen och genom att skapa individuella lösningar kan andraspråkseleverna ges möjlighet att få samma tillgång till fortsatta studier som förstaspråkselever har samt möjlighet att nå alla ämnens mål. Formulerat ideal är att undervisningen ska ha sin utgångspunkt i de enskilda elevernas behov och förutsättningar. Detta kan innebära att innehållet i andraspråksämnet tar avstamp i andra språk och kulturer än den svenska. På så vis kan ämnet betraktas som erfarenhetspedagogiskt med utgångspunkt i andraspråkselevernas erfarenheter. Att utforma och organisera undervisning olika är ett sätt att integrera och gynna elevers utveckling och ge förutsättningar för deltagande fullt ut. Härmed blir undervisningen också kompletterande. 
Min förhoppning är en ämneskursplan som på ett tydligt vis utgår från andraspråkselevernas speciella språkförvärvssituation där behov och förutsättningar styr, där alla elever fostras i ömsesidig respekt, där mångfald är utgångspunkt, olika språkliga och kulturella kompetensers betydelse för skolframgång betonas och olikheter kan befrukta varandra. Härigenom kan en interkulturell skolmiljö skapas där alla elever möts, deltar och samverkar. En ytterligare förhoppning är en kursplan för andraspråksämnet som på ett bättre sätt uttrycker hänsyn till att elever befinner sig på olika nivåer i språktillägnandet oberoende av fysisk ålder.

\section{REFERENSER}

Abbasian, Saeid (2003). Integration på egen hand. En studie av invandrade kvinnoföretagare i Sverige. Uppsala: Uppsala Universitet.

Abrahamsson, Bengt, Berg, Gunnar \& Wallin, Erik (1999). Organisations- och läroplansperspektiv. En väg mot en teori om skolan som institution. Pedagogisk Forskning i Sverige, 4(2) 145-161.

Alvesson, Mats \& Sköldberg, Kaj (1994). Tolkning och reflektion. Vetenskapsfilosofi och kvalitativ metod. Lund: Studentlitteratur.

Ball, Stephen (1994). Education reform. A critical and post-structural approach. Buckingham: Open University Press.

Bengtsson, Jan (1993). Sammanflätningar. Husserls och Merleau Pontys fenomenologi. Göteborg: Daidalos.

Berg, Gunnar (2003). Att förstå skolan. Lund: Studentlitteratur.

Bergström, Göran \& Boreus, Kristina (2000). Textens mening och makt. Metodbok $i$ samhällsvetenskaplig textanalys. Lund: Studentlitteratur.

Diskay, Suzanna (2002). Tolkning och förståelse. Stockholm: Natur och Kultur.

Elmeroth, Elisabeth (1997). Alla lika - Alla olika. Skolsituationen för elever med båda föräldrarna födda utomlands. Stockholm: Almqvist \& Wiksell International.

Elmeroth, Elisabeth (2005a). Svenska som andraspråk i en multikulturell skola. I Skolverket (Red.) Grundskolans ämnen $i$ ljuset av nationella utvärderingen 2003. Stockholm: Skolverket.

Elmeroth, Elisabeth (2005b). Svenska som demokratiämne. I Skolverket (Red.) Grundskolans ämnen $i$ ljuset av nationella utvärderingen 2003. Stockholm: Skolverket.

Englund, Tomas (1986). Curriculum as a political problem. Changing educational concepts with special references to citizenship education. Uppsala: Acta Universitatis Upsaliensis.

Englund, Tomas (1990). På väg mot en pedagogisk dynamisk analys av innehållet. Forskning om Utbildning, 17(1), 19-35.

Englund, Tomas (1995). Utbildningspolitiskt systemskifte? Stockholm: HLS Förlag.

Englund, Tomas (1998). The public and the text. Journal of Curriculum Studies, 28(1), $1-35$.

Englund, Tomas (1999). Talet om likvärdighet i svensk utbildningspolitik. I C.-A. Säfström \& L. Östman (Red). Textanalys. Lund: Studentlitteratur.

Englund, Tomas (2005). Läroplanens och skolkunskapens politiska dimension. Göteborg: Daidalos AB.

Goodlad, John, I. (1979). Curriculum inquiry. The study of curriculum practice. New York, McGraw-Hill. 
Haug, Peder (1998). Pedagogiskt dilemma: Specialundervisning. I Skolverkets monografiserie $n r$ 98:396. Stockholm: Liber.

Karlsudd, Peter (2002). "Tillsammans". Integreringens möjligheter och villkor. Kalmar: Institutionen för Hälso- och beteendevetenskap, Högskolan i Kalmar.

Kungliga Skolöverstyrelsen (1962). Läroplan för grundskolan. Stockholm: Kungliga Skolöverstyrelsen.

Kvale, Steinar (1997). Den kvalitativa forskningsintervjun. Lund: Studentlitteratur.

Lahdenperä, Pirjo (1997). Invandrarbakgrund eller skolsvårigheter? En textanalytisk studie av åtgärdsprogram för elever med invandrarbakgrund. Stockholm: HLS Förlag.

Lindgren, Sven-Åke (2000). Michel Foucault och sanningens historia. I P. Månsson (Red.). Moderna samhällsteorier. Stockholm: Prisma.

Lundgren, Ulf, P. (1972). Frame, factors and the teaching process. A contribution to curriculum theory and theory on teaching. Stockholm: Almqvist \& Wiksell.

Lundgren, Ulf, P. (1979/1989). Att organisera omvärlden. En introduktion till läroplansteori. Stockholm: Utbildningsförlaget.

Lundgren, Ulf, P., Svingby, Gunilla \& Wallin, Erik (1981). Från Lgr 69 till Lgr 80. Erfarenheter från SÖ:s läroplansarbete. Stockholm: Institutionen för pedagogik, Högskolan för lärarutbildning.

Lundgren, Ulf, P. (1984). Ramfaktorteorins historia. Stockholm: Symposion Bokförlag.

Lundgren, Ulf, P. (1992). Didaktikens namn. I S. Selander (Red.). Forskning om utbildning. Stockholm: Brutus Östlings Bokförlag Symposium.

Lundgren, Ulf, P. (1999). Ramfaktorteori och praktisk utbildningsplanering. Pedagogisk Forskning i Sverige, 4(1) 31-41.

Malmgren, Lars-Göran (1996): Svenskundervisning $i$ grundskolan. Lund: Studentlitteratur.

Molander, Joakim (2003). Vetenskapsteoretiska grunder. Historia och begrepp. Lund: Studentlitteratur.

Myndigheten för skolutveckling (2004). Kartläggning av svenska som andra språk. Dnr 2003:757. Stockholm: Myndigheten för skolutveckling.

Nordin-Hultman, Elisabeth (2004). Pedagogiska miljöer och barns subjektskapande. Stockholm: Liber.

Olsson, Ulf (1999). Att läsa en text med Foucaultinspirerad blick. I C.-A. Säfström \& L. Östman (Red.). Textanalys. Lund: Studentlitteratur.

Parszyk, Ing-Marie (1999). En skola för andra: Minoritetselevers upplevelse av arbetsoch livsvillkor i grundskolan. Stockholm: HLS Förlag.

Persson, Bengt (2001). Elevers olikheter och specialpedagogisk kunskap. Stockholm: Liber.

Popkewitz, Tomas (1997). The production of reason and power: Curriculum history and intellectual traditions. Journal of Curriculum Studies, 29(2) 131-164.

Proposition 1975:26. Om riktlinjer för invandrar-och minoritetspolitiken.

Proposition.1997/98:16. Sverige, framtiden och mångfalden - från invandrarpolitik till integrationspolitik.

Reid, William, A. (1999). Curriculum as institution and practice. Essays in the deliberative tradition. Mahwah, New Jersey \& London: Lawrence Erlbaum. 
Skolverket (1996). Grundskolan. Kursplaner och betygskriterier. Stockholm: Skolverket.

Skolverket (2000). Grundskolan. Kursplaner och betygskriterier 2000. Stockholm: Skolverket.

Skolverket (2004). Elever med utländsk bakgrund. Svar på regeringsuppdrag. Dnr.75:2004:545. Stockholm: Skolverket.

Skolöverstyrelsen (1969). Lgr69, Läroplan för grundskolan. Stockholm: Skolöverstyrelsen.

Skolöverstyrelsen (1969). Lgr69 II, Läroplan för grundskolan. Undervisning av invandrarbarn $m \mathrm{fl}$. Stockholm: Skolöverstyrelsen

Skolöverstyrelsen (1973). Lgr69 II, Läroplan för grundskolan. Undervisning av invandrarbarn $\mathrm{m} f l$. Stockholm: Skolöverstyrelsen

Skolöverstyrelsen (1980). Lgr80, Läroplan för grundskolan. Stockholm: Skolöverstyrelsen.

Skolöverstyrelsen (1985:4). Kommentarmaterial Lgr80. Svenska som andraspråk. Grundläggande färdigheter. Stockholm: Skolöverstyrelsen.

SOU 1971:51. Invandrarutredningen 1. Invandrarna och minoriteterna. Invandrarnas utbildningssituation. Förslag om grundutbildning för vuxna invandrare. Stockholm: Inrikesdepartementet.

SOU 1974:69. Invandrarutredningen 3. Invandrarna och minoriteterna. Huvudbetänkande från invandrarutredningen. Stockholm: Arbetsmarknadsdepartementet.

Svenska Akademien, (1994). Svenska Akademiens ordlista över svenska språket. Stockholm: Norstedts Förlag.

Säfström, Carl-Axel (1994). Makt och mening. Förutsättningar för innehållsfokuserad pedagogisk forskning. Uppsala: Acta Universitatis Upsaliensis.

Säfström, Carl-Axel (1998). Svensk läroplansteoretisk forskning: Nostalgi eller nytänkande? Pedagogisk Forskning i Sverige, 3(2) 130-141.

Säfström, Carl-Axel (1999). Att förskjuta perspektiv: Läsning som omvänd hermeneutik. I C.-A. Säfström \& L. Östman (Red.). Textanalys. Lund: Studentlitteratur.

Tingbjörn, Gunnar (1981). Invandrarbarnen och tvåspråkigheten. I Skolöverstyrelsen (Red). Invandrarbarnen och tvåspråkigheten. FoU rapport 40. Stockholm: Skolöverstyrelsen.

Tingbjörn, Gunnar (2000). Svenska som andraspråk - ett ämne i tiden. I H. Åhl (Red). Svenska i tiden - verklighet och visioner. Stockholm: HLS Förlag.

Tingbjörn, Gunnar (2004). Svenska som andraspråk i ett utbildningspolitiskt perspektiv - en tillbakablick. I K. Hyltenstam \& I. Lindberg. Svenska som andraspråk - forskning, undervisning och samhälle. Lund: Studentlitteratur.

Torpsten, Ann-Christin (2004). Swedish as a second language in the national curriculum of Sweden. Conference paper. Hannover: TESSLA, University of Hannover.

Torpsten, Ann-Christin (2006). Ett monokulturellt erbjudande. Om svenska som andraspråk $i$ grundskolans läro- och kursplaner. Växjö: Institutionen för pedagogik, Växjö universitet.

Utbildningsdepartementet (1994). Läroplaner för det obligatoriska skolväsendet och de frivilliga skolformerna. Lpo 94, Lpf $94 . \quad$ Stockholm: Utbildningsdepartementet. 
Wahlström, Ninni (2002). Om det förändrade ansvaret för skolan. Vägen till mål-och resultatstyrning och några av dess konsekvenser. Örebro: Department of Education, Örebro University.

Östman, Leif (1995). Socialisering och mening. No-utbildning som politiskt och miljömoraliskt problem. Uppsala: Acta Universitatis Upsaliensis. 